\title{
Synthesis and biological evaluation of potential substrates for the
} isolation of the strigol receptor

\section{J an W illem J . F. T huring, R olf Keltjens, G erard H , L . N efkens and Binne $Z$ wanenburg*}

NSR-C entre for M olecular Structure, D esign and Synthesis, D epartment of O rganic Chemistry, U niversity of Nijmegen, Toernooiveld, $6525 \mathrm{ED} \mathrm{N}$ ijmegen, The $\mathrm{N}$ etherlands

\begin{abstract}
A series of analogues derived from (+)-strigol, which is a germination stimulant for seeds of the parasitic weeds Striga and 0 robanche, has been prepared. For the isolation and characterization of the strigol receptor, labelled analogues are required in which a photoreactive function may be incorporated. The synthetic strategy allows for the synthesis of a range of A-ring substituted analogues of G R 24 (which is a strigol analogue), including fluorescent dansyl G R 24 10. Bioassays reveal that the stimulatory activity of these analogues in the seed germination of Striga hermonthica is retained.
\end{abstract}

\section{Introduction}

Parasitic weeds belonging to the genera Striga and Orobanche severely reduce yields of economically important crops in tropical and semitropical areas of the eastern hemisphere. ${ }^{1,2}$ The parasitic process begins with the seed germination of the weeds, induced by a stimulant which is present in the root exudate of the host plant. Following the isolation and identification of the naturally occurring germination stimulant (+)-strigol (Fig. 1), ${ }^{3,4}$ several structure-bioactivity studies have been

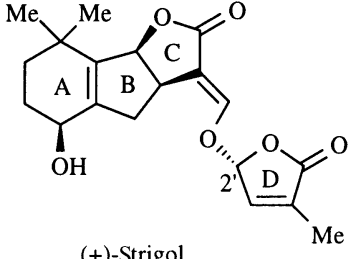

(+)-Strigol

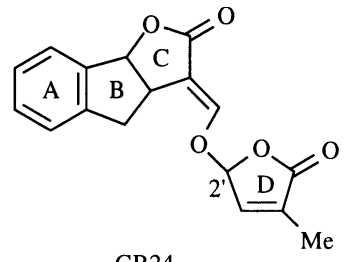

GR24
Fig. 1

conducted, which revealed that the bioactiphore resides in the $C D$-fragment and the vinyl ether moiety. ${ }^{5-10}$

In particular, G R 24 (F ig. 1) turned out to be a highly potent synthetic strigol analogue ${ }^{5,6,11}$ Based on the structural requirements for retaining stimulatory activity a tentative molecular mechanism for germination has been proposed $^{8}$ which is depicted in Scheme 1.

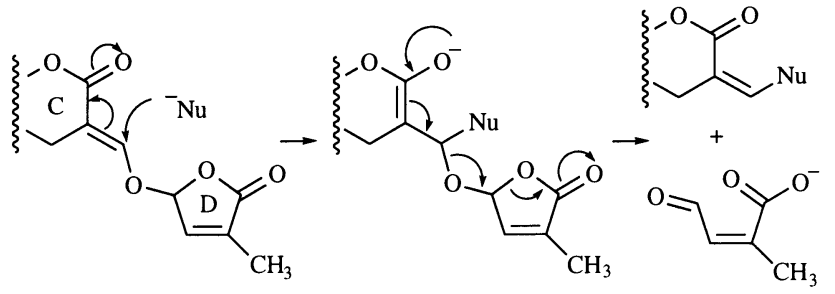

Scheme 1

A ccording to this mechanism a nucleophilic site in the receptor cavity reacts with the $M$ ichael acceptor unit, followed by elimination of the D-ring. The $C$ - and D-rings as well as the connecting vinyl ether unit play an important role in inducing the germination. It is thus suggested that the chemical reaction at the receptor site is of crucial importance at the very beginning of the signal-transduction chain. However, nothing is known about the protein structure nor of its localization within the seeds. Detailed knowledge of the receptor protein would enable the design of a perfectly fitting substrate. Current strategies in the purification of plant proteins involve several types of affinity chromatography and photoaffinity labelling. ${ }^{12}$ In photoaffinity labelling the substrate of the protein is converted into a photo affinity ligand by covalently attaching a photoreactive moiety, such as an azido group, to the natural ligand. ${ }^{13}$ A fter exposure to a cell extract, a very short-living, highly reactive intermediate is generated upon irradiation, which will be covalently bonded onto the protein in the vicinity of the putative ligand-binding site. A radioactive or fluorescent tag can be introduced in the photoreactive ligand in order to allow detection during isolation and enable the characterization of the protein. ${ }^{14}$ It has been demonstrated that this technique is a useful tool in plant hormone research, exemplified by the photoaffinity labelling of auxin binding proteins ${ }^{15}$ and gibberellin binding proteins. ${ }^{16}$ In the case of the strigol receptor, incorporation of a photoreactive moiety may not strictly be necessary. If the molecular mechanism (Scheme 1) is correct, treatment of the seeds with a radioactive or fluo rescent strigol analogue may directly lead to covalent attachment to the receptor protein without the need to generate a highly reactive species by irradiation. When the bioactiphore of the ligand is known, incorporation of the tag and eventually a photolabile moiety should be such that the bioactivity is retained. Structure-activity relationship studies, which have previously been performed ${ }^{8-10}$ will, therefore, provide a firm basis for the design of suitable compounds for the isolation of the strigol receptor.

Here synthetic approaches are described for the preparation of biologically active, labelled strigol analogues, suitable for, at least in principle, the identification of the strigol receptor. The synthetic concept is a general approach to a wide range of substrates containing a tag and eventually an additional photolabile moiety. In addition, the activity of the stimulation of seed germination of Striga hermonthica (D el.) Benth. and O robanche crenata Forsk. of some of the thus obtained strigol analogues is evaluated.

\section{Results and discussion}

\section{Strategy}

In designing potential labelled germination stimulants, GR 24 (Fig. 1) was used as the lead molecule. The bioactivity of GR 24 is very high and its preparation is well documented. ${ }^{11}$ Since the CD -part as well as the connecting enol ether unit are 
essential for full biological activity, ${ }^{8,17}$ it was suggested that the tag and/or photoreactive group can best be incorporated into the A-ring of the stimulant molecule. A mino tricylic lactone 1 and amino GR 242 were selected as appropriate compounds to serve this purpose as a wide range of transformations are feasible with these synthons, such as acylation, sulfonylation or alkylation, whereby coupling with an external tag can be achieved. The strategy for the synthesis of labelled GR 24 analogues is outlined in Scheme 2 . The label may be introduced

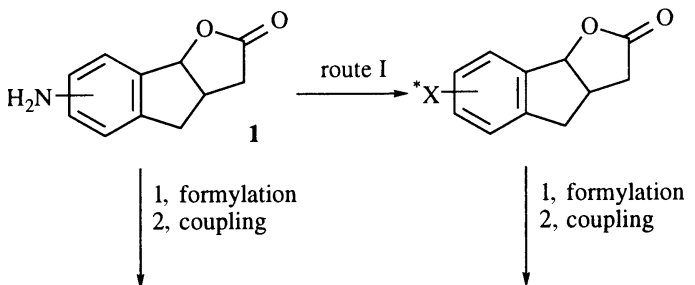

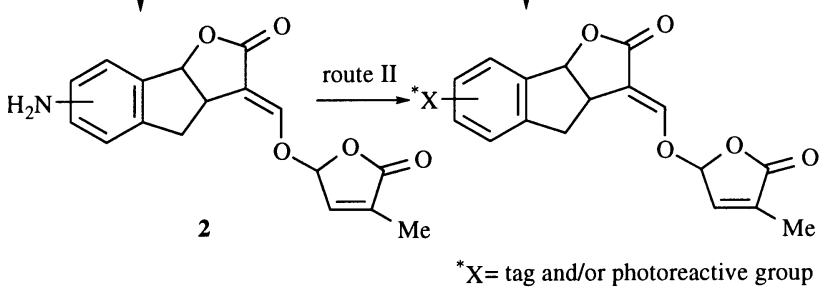

Scheme 2

either before (route I) or after (route II) coupling with the D-ring.

\section{Synthesis}

In our strategy the main issue is the introduction of an amino function into the A-ring of tricyclic lactone $3^{11}$ in a regiocontrolled manner (Scheme 3).<smiles>CC1CC2CC(=O)OC2c2ccccc21</smiles><smiles>O=C1CC2Cc3ccc([N+](=O)[O-])cc3C2O1</smiles><smiles>O=C1CC2Cc3ccc(I)cc3C2O1</smiles>

$12 \mathbf{a}$

+ 5-iodo-isomer 12b

$12 \mathbf{a}: 12 \mathbf{b}=1: 1$

Scheme 3 Reagents: $a, \mathrm{NaNO}_{3}, \mathrm{TFA} ; \mathrm{b}, \mathrm{Sn}-\mathrm{HCl}$ (aq.), heat; $\mathrm{c}, \mathrm{I}_{2}$, $\mathrm{Phl}\left[\mathrm{OC}(\mathrm{O}) \mathrm{CF}_{3}\right]_{2}$

This was achieved via nitration of $\mathbf{3}$ under relatively mild conditions (Scheme 3), ${ }^{18}$ to give two regioisomeric lactones $\mathbf{4 a}$ and $\mathbf{4 b}$ in a ratio of 9:1 in excellent yield, which could readily be separated. The structure of $4 a$ was deduced unambiguously from a 2D-N OESY experiment. The preferred formation of $4 a$ can be explained by the fact that $\mathrm{C}-7$ is the least electrondeficient carbon atom in the aromatic ring. The nitration under similar conditions to ok place also starting from $G R 24$ to give 7nitro GR24 5a and its 5-nitro isomer $\mathbf{5 b}$ in a ratio of $9: 1$ (Scheme 4).

H owever, several attempts to obtain amino G R 242 by reduction of the nitro function in $\mathbf{5}$ were unsuccessful. In contrast, reduction of the nitro group in 4 a was accomplished employing aqueous $\mathrm{Cu}(\mathrm{OAC})_{2}$ and $\mathrm{NaBH}_{4}$ in methanol ${ }^{\mathbf{1 9}}$ in yields in the range $34-95 \%$. A more reliable procedure (Scheme 3 ) involves<smiles>CC(=O)O[C@H]1C=C(C)C(=O)O1</smiles>

GR24<smiles>[Z][X]C([CH])(C)C</smiles>

5a, $\mathrm{X}=\mathrm{NO}_{2}, \mathrm{Y}=\mathrm{H}$

$\mathbf{5 b}, \mathrm{X}=\mathrm{H}, \mathrm{Y}=\mathrm{NO}_{2}$

$5 \mathbf{a}: 5 \mathbf{b}=9: 1$

Scheme 4 Reagents: $a$, TFA, $\mathrm{NaNO}_{3}$

the use of $\mathrm{Sn}-\mathrm{HCl}$ under reflux, ${ }^{20}$ which gave the 7-amino tricyclic lactone 1a in a reproducible yield of $99 \%$ ( $77 \%$ after recrystallization). The preparation of amino GR24 $2 a$ from amino tricyclic lactone 1a involves a four-step procedure as is depicted in Scheme 5.

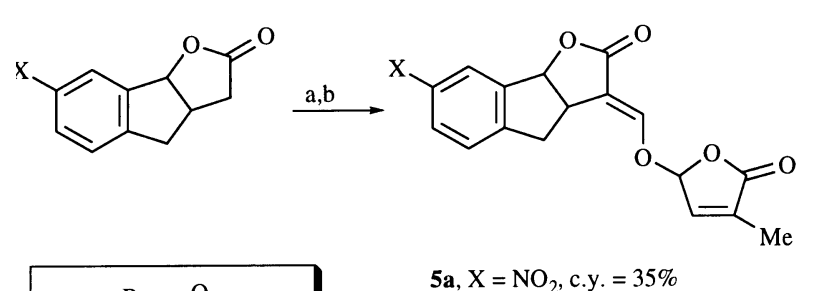

7:

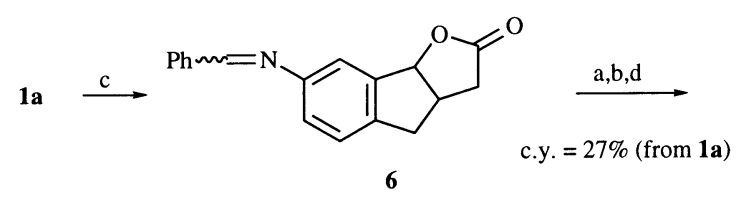<smiles>CC1=CC(O/C=C2\C(=O)OC3c4cc(N)ccc4CC23)OC1=O</smiles>

Scheme 5 Reagents: $\mathrm{a}, \mathrm{KOBu}^{\mathrm{t}}, \mathrm{HCO}_{2} \mathrm{Me}$; b, bromo butenolide 7; $\mathrm{c}$, $\mathrm{PhCHO}$, mol. sieves; $\mathrm{d}_{1} \mathrm{SiO}_{2}$

The amino group in la was first protected as a Schiff base 6 by reaction with benzaldehyde, then followed by formylation, coupling with bromo butenolide 7, similar to that described for G R 24, ${ }^{11}$ and finally deprotection. Crude 7-benzalimino G R 24 was isolated in an overall yield of $78 \%$, based on 1 a. D eprotection was not as straightforward as expected. Several conventional methods, such as $5 \%$ oxalic acid, failed to give the desired result and only starting imine was recovered. H owever, during purification of 7-benzalimino GR24 by flash chromatography, the deprotection took place on the silica gel column and amino G R 24 2a was isolated in an overall yield of $27 \%$. The diastereoisomers could not be separated, neither by flash chromatography nor by recrystallization, in contrast to G R 24. ${ }^{11}$

The key intermediate amino GR 24 2a was then utilized for further derivatization (Scheme 6), especially for the purpose of receptor identification.

Diazotation and substitution ${ }^{21}$ in the presence of $\mathrm{NaN}_{3}$ gave 8, which is thermally rather unstable, in high yield. A pplying the appropriate sulfonyl chloride, mesyl G R 249 and dansyl G R 24 10 were synthesized in high yields. ${ }^{22}$ The alternative procedure for the preparation of the labelled G R 24 analogues 8, 9 and 10, involving modification of the amino function of 1 a into the azido, mesylamino and dansylamino group, respectively, fol- 


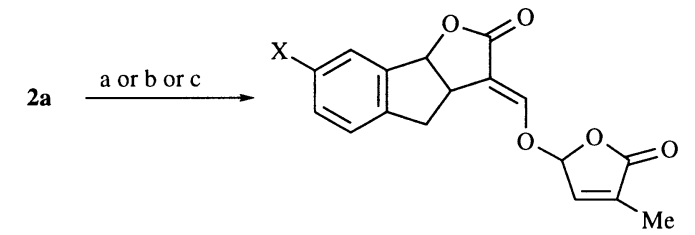

9, $\mathrm{X}=\mathrm{NHMs}, \mathrm{c} . \mathrm{y} .=78 \%$

10, $X=$ NHDans, c. $y .=89 \%$

$8, X=\mathrm{N}_{3}$, c.y. $=88 \%$

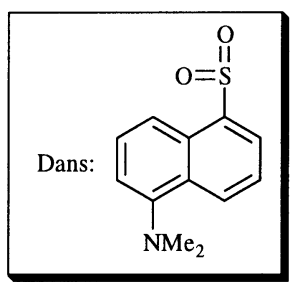

Scheme 6 Reagents and conditions: $a, X=$ NHM s: pyridine, $\mathrm{M} \mathrm{SCl}$ b, $\mathrm{X}=\mathrm{NH}$ Dans: pyridine, $\mathrm{D}$ ansCl; $\mathrm{c}, \mathrm{X}=\mathrm{N}_{3}: 1, \mathrm{~N}^{2} \mathrm{NO}_{2}, 80 \% \mathrm{HOAC}$; $2, \mathrm{NaN}_{3}$

lowed by coupling with the D -ring (route I in Scheme 2), is less attractive, as the yields are low to moderate ${ }^{23}$ and the purification of the compounds prepared via route II is much simpler than by route I (Scheme 2).

The synthesis of 7-iodo G R 2411 could not be accomplished starting from $2 \mathrm{a}$, since the substitution of the diazo moiety by iodide, in a similar procedure to that used for the preparation of azido GR 248 (vide supra), was unsuccessful. Therefore, the tricyclic lactone $\mathbf{3}$ was iodinated (cf. route I in Scheme 2) employing iodine in the presence of [bis(trifluoroacetoxy)iodobenzene] (Scheme 3 ) by adopting the procedure of M erkushev et al. ${ }^{24} \mathrm{~A}$ 1:1 mixture of the regioisomeric 7-iodo lactone $12 \mathrm{a}$ and the 5 -iodo lactone $\mathbf{1 2} \mathbf{b}$ was obtained in an excellent yield, which could readily be separated. Structural assignments were performed by comparison with the ${ }^{1} \mathrm{H} N \mathrm{~N}$ R spectra of the 7nitro and 5 -nitro counterparts $4 \mathbf{a}$ and $\mathbf{4 b}$ respectively. Coupling reactions of $4 a$ and $12 a$ to give the desired G R 24 analogues via route I (Scheme 2) involve a two-step procedure (Scheme 5), similar to that described for the synthesis of GR $24 .{ }^{11}$ For the preparation of 7-nitro G R 245 a this sequence was carried out in a one-pot procedure to give $5 \mathrm{a}$ as an approximately $1: 1$ mixture of diastereoisomers in a moderate overall yield of $35 \%$. H owever, for the preparation of 7-iodo G R $24 \mathbf{1 1}$ it was found more appropriate to isolate the intermediate hydroxymethyleno lactone, which could readily be purified by washing with diethyl ether to remove unchanged starting material, although some loss of material had to be accepted. A lkylation with the bromo butenolide 7 provides 7-iodo G R 2411 as an approximately $1: 1$ mixture of diastereoisomers, which could readily be separated by flash chromatography.

\section{B iological activity}

The stimulatory activity of nitro GR24 5a, amino GR24 2a and dansyl GR24 10 was determined using seeds of Striga hermonthica and 0 robanche crenata. The germination percentages are collected in Tables 1 and 2, together with those obtained for G R 24 under the same conditions in the same bioassay. This reference to GR 24 enables a comparison between results obtained in different test series, which is important, because the response of seeds of parasitic weeds, in particular of Striga hermonthica, varies considerably from test to test. For bioassays of nitro G R 24 5a and dansyl G R 24 10, the fastmoving diastereoisomers were used, whereas amino GR 24 2a was tested as a mixture of diastereoisomers. It was shown for GR24 that the activity of the most active (fast-moving) diastereo isomer is not seriously influenced by the presence of the less active diastereoisomer. ${ }^{11}$

The data in Tables 1 and 2 reveal that compounds $2 \mathbf{a}, 5 \mathbf{a}$ and
Table 1 G ermination percentages for seeds of Striga hermonthica after exposure to solutions of $\mathbf{2 a}, \mathbf{5 a}$ and $\mathbf{1 0}$ at different concentrations $\mathrm{s}^{\mathrm{a}}$

\begin{tabular}{llccc}
\hline \multicolumn{5}{c}{$\%$ Germination \pm SE at } \\
\cline { 3 - 5 } Entry & Compound & $1 \mathrm{mg} \mathrm{I}^{-1}$ & $0.01 \mathrm{mg} \mathrm{I}^{-1}$ & $0.001 \mathrm{mg} \mathrm{I}^{-1}$ \\
\hline 1 & \multirow{2}{*}{$\mathbf{1 0}$} & $70.0 \pm 1.9$ & $57.8 \pm 3.0$ & $19.4 \pm 1.3$ \\
& & $(40.3 \pm 2.4)^{\mathbf{b}}$ & $(50.1 \pm 2.8)^{\mathbf{b}}$ & $(21.4 \pm 1.7)^{\mathbf{b}}$ \\
2 & $\mathbf{5 a}$ & $54.1 \pm 4.3$ & $59.3 \pm 4.6$ & $44.1 \pm 2.2$ \\
& & $(51.1 \pm 2.4)^{\mathbf{b}}$ & $(60.1 \pm 3.0)^{\mathbf{b}}$ & $(32.4 \pm 2.0)^{\mathbf{b}}$ \\
3 & $\mathbf{2 a}$ & $46.9 \pm 3.8$ & $17.5 \pm 2.2$ & $7.1 \pm 1.9$ \\
& & $(50.5 \pm 1.2)^{\mathbf{b}}$ & $(54.8 \pm 1.4)^{\mathbf{b}}$ & $(29.0 \pm 5.5)^{\mathbf{b}}$ \\
4 & Control $^{\mathbf{c}}$ & $9.8 \pm 0.5$ & $11.2 \pm 1.3$ & $9.8 \pm 0.8$ \\
\hline
\end{tabular}

a $G$ ermination percentages given are the mean of two replicate tests. In each test the percentage was determined 12 times by counting the number of germination seeds. ${ }^{b}$ Thevaluesin parenthesesarethemean germination percentages for seeds tested under the same conditions and at the same time, with G R 24 as stimulant. ' A queous control containing 0.1, 0.001 and $0.0001 \%(\mathrm{v} / \mathrm{v})$ acetone.

Table 2 G ermination percentage for seeds of O robanche crenata after exposure of $\mathbf{2 a}, \mathbf{5 a}$ and $\mathbf{1 0}$ at different concentrations ${ }^{\mathbf{a}}$

\begin{tabular}{|c|c|c|c|c|}
\hline \multirow[b]{2}{*}{ Entry } & \multirow[b]{2}{*}{ Compound } & \multicolumn{3}{|c|}{$\%$ G ermination $\pm \mathrm{SE}$ at } \\
\hline & & $1 \mathrm{mg} \mathrm{l}^{-1}$ & $0.1 \mathrm{mg} \mathrm{I}^{-1}$ & $0.01 \mathrm{mg} \mathrm{I}^{-1}$ \\
\hline 1 & 10 & $\begin{array}{c}1.5 \pm 0.6 \\
(60.7 \pm 2.8)^{b}\end{array}$ & $\begin{array}{c}0.0 \pm 0.0 \\
(27.3 \pm 3.6)^{b}\end{array}$ & $\begin{array}{c}0.2 \pm 0.2 \\
(1.2 \pm 0.9)^{b}\end{array}$ \\
\hline 2 & $5 a$ & $\begin{array}{c}56.7 \pm 3.5 \\
(60.0 \pm 3.1)^{b}\end{array}$ & $\begin{array}{c}9.3 \pm 1.6 \\
(27.3 \pm 3.6)^{b}\end{array}$ & $\begin{array}{c}1.2 \pm 0.3 \\
(1.6 \pm 0.4)^{b}\end{array}$ \\
\hline 3 & $2 a$ & $\begin{array}{c}33.6 \pm 3.5 \\
(58.1 \pm 3.8)^{b}\end{array}$ & $\begin{array}{c}2.7 \pm 1.0 \\
(24.7 \pm 2.4)^{b}\end{array}$ & $\begin{array}{l}0.0 \pm 0.0 \\
(0.1 \pm 0.1)^{b}\end{array}$ \\
\hline 4 & Control ${ }^{c}$ & $0.0 \pm 0.0$ & $0.0 \pm 0.0$ & $0.0 \pm 0.0$ \\
\hline
\end{tabular}

a $G$ ermination percentages given are the mean of two replicate tests. In each test the percentage was determined 12 times by counting the number of germination seeds. ${ }^{\mathbf{b}}$ The values in parentheses are the mean germination percentages for seeds tested under the same conditions and at the same time, with G R 24 as stimulant. ' A queous control containing $0.1,0.01$ and $0.0001 \%(v / v)$ acetone

10 behave quite differently towards seeds of Striga hermonthica and Orobanche crenata. In the case of Striga hermonthica, the biological activity of the substituted GR 24 derivatives is relatively little affected as compared to GR24. The activity of amino GR24 2a is about one order of magnitude lower than GR24, whereas nitro GR24 5a and dansyl GR24 10 possess comparable concentration-dependent activities. Interestingly, the intrinsic activity of dansyl G R 2410 is considerably higher than that of GR 24, which becomes apparent at the higher concentrations. In contrast, dansyl G R 2410 is completely inactive in the stimulation of O robanche crenata seeds. Evidently, substituents in the A-part of GR24 have a negative effect on the bioactivity in the case of this parasitic species. The difference in response exerted by $A$-ring anologues $2 a, 5 a$ and $\mathbf{1 0}$ on seeds of Striga hermonthica and Orobanche crenata is rather unexpected, since previous studies revealed that structural modifications in the BC-part, ${ }^{9}$ enol ether moiety ${ }^{25}$ and D-ring ${ }^{26}$ generally give similar results for both parasitic species. $\mathrm{N}$ evertheless, the prospects of incorporating a tag in the A-ring of GR 24 with the aim of identifying the receptor protein is very promising for Striga hermonthica. The remarkable activity of the bulky dansyl derivative $\mathbf{1 0}$ suggests a large degree of structural freedom in the A-part with retention of full biological activity.

\section{Conclusion}

In this synthetic study the preparation of amino GR24 $2 \mathbf{a}$ is described. This compound is a versatile synthon for the preparation of a range of A-ring analogues of $G$ R 24. The synthesis of the fluorescent GR24 analogue 10 has been accomplished. A pplication of the thus developed synthetic strategy provides a feasible approach to the incorporation of radioactive tags and 
photoreactive units in the GR 24 molecule. The germination stimulatory activity of G R 24 analogues $\mathbf{2 a}, \mathbf{5 a}$ and $\mathbf{1 0}$ is relatively little affected for seeds of Striga hermonthica, whereas it is considerably reduced for seeds of O robanche crenata. Therefore Striga hermonthica is an attractive target to perform protein fishing experiments.

\section{Experimental}

\section{Synthesis}

N omenclature. We have used the AU TON OM 1.0 program, provided by the Beilstein Institute and Springer Verlag, Weinheim, BR D

G eneral remarks. $100 \mathrm{M} \mathrm{Hz}^{1} \mathrm{H}$ N M R Spectra and $400 \mathrm{M} \mathrm{Hz}$ ${ }^{1} \mathrm{H}$ N M R spectra were recorded on a Bruker AC 100 spectrometer and a Bruker A M -400 spectrometer, respectively ( $\mathrm{M} \mathrm{e}_{4} \mathrm{Si}$ as internal standard). A Il coupling constants are given as ${ }^{3}$ in $\mathrm{Hz}$, unless indicated otherwise. IR Spectra were recorded on Perkin-Elmer $298 \mathrm{IR}$ spectrophotometer. For mass spectra a double focussing VG 7070E mass spectrometer was used. GCMS Experiments were run on a Varian Saturn 2 GC-M S ion-trap system. Separation was carried out on a fused-silica capillary column (D B -5, $30 \mathrm{~m} \times 0.25 \mathrm{~mm}$ ). H elium was used as carrier gas, and electron impact (EI) was used as ionization mode. GLC was conducted with a Hewlet-Packard HP 5890 gas chromatograph, using a capillary column ( $25 \mathrm{~m}$ ) of H P-1 and nitrogen ( $2 \mathrm{ml} \mathrm{min}^{-1}, 0.5 \mathrm{~atm}$ ) as the carrier gas. M elting points were measured with a Reichert Thermopan microscope and are uncorrected. Elemental analyses were performed at the D epartment of $\mathrm{M}$ icro-analysis of this laboratory. F luorescence measurements were performed using a Perkin-EImer luminescence spectrometer LS50B. Solvents were dried using the following methods: dichloromethane was distilled from $\mathrm{P}_{2} \mathrm{O}_{5}$; diethyl ether distilled from $\mathrm{NaH}$; hexane was distilled from $\mathrm{CaH}_{2}$; tetrahydrofuran was distilled from lithium aluminium hydride just before use. All other solvents were of analytical grade. Thin layer chromatography (TLC) was carried out on $M$ erck pre-coated silica gel $60 \mathrm{~F} 254$ plates $(0.25 \mathrm{~mm})$ using the eluents indicated. Spots were visualized with UV or using molybdate spray. F lash chromatography was carried out at a pressure of ca. 1.5 bar, using M erck K ieselgel $60 \mathrm{H}$. Column chromatography at atmospheric pressure was carried out, using M erck K ieselgel 60 .

3,3a,4,8b-Tetrahydroindeno[1,2-b]furan-2-one 3 and 5bromo-3-methylfuran-2(5H)-one 7 were prepared according to known procedures. ${ }^{11}$

\section{7-N itro-3,3a,4,8b-tetrahydroindeno[1,2-b]furan-2-one 4a and 5-} nitro-3,3a,4,8b-tetrahydroindeno[1,2-b]furan-2-one $4 \mathrm{~b}$

Sodium nitrate $(0.51 \mathrm{~g}, 6.0 \mathrm{mmol})$ was added to a solution of the tricyclic lactone 3 (348 $\mathrm{mg}, 2.00 \mathrm{mmol}$ ) in TFA (15 ml) at room temperature. The solution was stirred overnight after which TFA was removed in vacuo, and the residue was dissolved in ethyl acetate and saturated aqueous $\mathrm{NaHCO}_{3}$. The aqueous phase was extracted with ethyl acetate $(2 x)$. The combined extracts were dried $\left(\mathrm{M} \mathrm{gSO}_{4}\right)$, filtered and concentrated in vacuo to give a mixture of $\mathbf{4 a}$ and $\mathbf{4 b}(399 \mathrm{mg}, 91 \%)$ as a solid. The ratio of $\mathbf{4 a : 4 b}(9: 1)$ was determined by ${ }^{1} \mathrm{H} N \mathrm{~N} \mathrm{R}(100 \mathrm{M} \mathrm{Hz})$ analysis. Pure $4 a(319 \mathrm{mg}, 75 \%)$ was obtained by recrystallization from toluene. The residue, containing $\mathbf{4 b}$, was purified by flash chromatography $\left(\mathrm{SiO}_{2}\right.$, hexane-ethyl acetate, $\left.1: 1\right)$ to give pure $4 \mathrm{~b}$ ( $40 \mathrm{mg}, 9 \%$ ) as a white solid. A n analytically pure sample was obtained by crystallization from hexane-ethyl acetate.

Compound $4 \mathrm{a}, \mathrm{R}_{\mathrm{f}} 0.21$ (hexane-ethyl acetate, $1: 1$ ), mp 118$119{ }^{\circ} \mathrm{C}$ (from hexane-ethyl acetate) (Found: $\mathrm{C}, 60.12 ; \mathrm{H}, 4.04$; $\mathrm{N}, 6.37 . \mathrm{C}_{11} \mathrm{H}_{9} \mathrm{~N} \mathrm{O}_{4}$ requires $\left.\mathrm{C}, 60.28 ; \mathrm{H}, 4.14 ; \mathrm{N}, 6.39\right) ; \delta_{\mathrm{H}}(400$ $\left.\mathrm{M} \mathrm{Hz} \mathrm{CDCl}_{3}\right) 2.43\left(1 \mathrm{H}, \mathrm{dd}^{2}{ }^{2} \mathrm{~J} 18.2\right.$, J 5.3, 3-H ), $2.96(1 \mathrm{H}, \mathrm{dd}$, 2. $18.2, \mathrm{~J} 9.7,3-\mathrm{H}), 3.00\left(1 \mathrm{H}, \mathrm{dd},{ }^{2} \mathrm{~J} 17.2, \mathrm{~J} 3.4,4-\mathrm{H}\right), 3.44(1 \mathrm{H}$ dd, ${ }^{2} \mathrm{~J} 17.2$, J 8.6, $\left.4 \mathrm{H}\right), 3.52(1 \mathrm{H}, \mathrm{m}, 3 \mathrm{a}-\mathrm{H}), 5.94(1 \mathrm{H}, \mathrm{d}, \mathrm{J} 7.1$, 8b-H ), $7.45(1 \mathrm{H}, \mathrm{d}, \mathrm{J} 8.4,5-\mathrm{H}), 8.25(1 \mathrm{H}, \mathrm{dd}, 4 \mathrm{~J} 2.1, \mathrm{~J} 8.4,6-\mathrm{H})$ and $8.35(1 \mathrm{H}, \mathrm{d}, 4 \mathrm{f} 2.1,8-\mathrm{H}) ; \mathrm{m} / \mathrm{z} 219\left(\mathrm{M}^{+}, 39 \%\right), 175(100$, $\left.\mathrm{C}_{10} \mathrm{H}_{9} \mathrm{~N} \mathrm{O}_{2}\right), 128\left(84, \mathrm{C}_{10} \mathrm{H}_{8}\right)$ and $115\left(33, \mathrm{C}_{9} \mathrm{H}_{7}\right)$.

Compound $\mathbf{4 b}, \mathrm{R}_{\mathrm{f}} 0.35$ (hexane-ethyl acetate, $1: 1$ ) mp 137$140{ }^{\circ} \mathrm{C}$ (from hexane-ethyl acetate) (Found: $\mathrm{C}, 59.93 ; \mathrm{H}, 4.02$; $\mathrm{N}, 6.34 . \mathrm{C}_{11} \mathrm{H}_{9} \mathrm{~N} \mathrm{O}_{4}$ requires $\left.\mathrm{C}, 60.28 ; \mathrm{H}, 4.14 ; \mathrm{N}, 6.39\right) ; \delta_{\mathrm{H}}(100$ $\left.\mathrm{M} \mathrm{Hz} \mathrm{CD} \mathrm{Cl}_{3}\right) 2.46\left(1 \mathrm{H}, \mathrm{dd},{ }^{2} \mathrm{~J} 18.1, \mathrm{~J} 5.0,3-\mathrm{H}\right), 2.90(1 \mathrm{H}, \mathrm{dd}$, 2. $18.1, \mathrm{~J} 9.5,3-\mathrm{H}), 3.29-4.00(3 \mathrm{H}, \mathrm{m}, 4-\mathrm{H}$ and $3 \mathrm{a}-\mathrm{H}), 5.95(1 \mathrm{H}$, $\mathrm{d}, \mathrm{J} 7.4,8 \mathrm{~b}-\mathrm{H}), 7.53(1 \mathrm{H}, \mathrm{t}, \mathrm{J} 7.7,7-\mathrm{H}), 7.83(1 \mathrm{H}, \mathrm{d}, \mathrm{J} 7.7,8-\mathrm{H})$ and $8.25(1 \mathrm{H}, \mathrm{d}, \mathrm{J} 7.7,6-\mathrm{H}) ; \mathrm{m} / \mathrm{z} 219\left(\mathrm{M}^{+}, 28 \%\right), 128(100$, $\left.\mathrm{C}_{10} \mathrm{H}_{8}\right)$ and $115\left(54, \mathrm{C}_{9} \mathrm{H}_{7}\right)$.

\section{7-A mino-3,3a,4,8b-tetrahydroindeno[1,2-b]furan-2-one $1 \mathrm{a}$}

A mixture containing the 7-nitro tricyclic lactone $4 \mathrm{a}(3.00 \mathrm{~g}$, $13.7 \mathrm{mmol}$ ) and tin (powdered, $17.7 \mathrm{~g}, 0.149 \mathrm{~mol}$ ) in ethanol (63 $\mathrm{ml})$ and $10 \mathrm{M} \mathrm{HCl}(59 \mathrm{ml})$ was heated at reflux for $1 \mathrm{~h}$. A fter cooling of the reaction mixture, it was evaporated in vacuo to remove the ethanol and then adjusted to $\mathrm{pH} 8$ by the addition of saturated aqueous $\mathrm{NaHCO}_{3}$. Insoluble tin salts were removed by filtration over $\mathrm{H}$ yflo. The mixture was extracted with ethyl acetate $(3 x)$ and the combined extracts were dried $\left(\mathrm{M} \mathrm{gSO}_{4}\right.$ ) and evaporated in vacuo to afford crude la as a brownish solid $(2.56 \mathrm{~g}, 99 \%)$. R ecrystallization of this from ethyl acetate provided analytically pure $1 \mathrm{a}(1.99 \mathrm{~g}, 77 \%)$ as pale yellow crystals, mp $128-130^{\circ} \mathrm{C}$ (from ethyl acetate) (Found: $\mathrm{C}, 69.47$; $\mathrm{H}, 5.81 ; \mathrm{N}, 7.30 . \mathrm{C}_{11} \mathrm{H}_{11} \mathrm{~N} \mathrm{O}_{2}$ requires $\mathrm{C}, 69.83 ; \mathrm{H}, 5.86 ; \mathrm{N}$, 7.40); $\delta_{\mathrm{H}}\left(100 \mathrm{M} \mathrm{Hz} \mathrm{CDCl}_{3}\right) 2.22\left(1 \mathrm{H}, \mathrm{dd},{ }^{2} \mathrm{~J} 17.9\right.$, J 5.5, 3- $\left.\mathrm{H}\right)$, 2.54-3.05 (4 H, m, 3-H, 4- $\mathrm{H}$ and $3 \mathrm{a}-\mathrm{H}), 3.70\left(2 \mathrm{H}, \mathrm{br} \mathrm{s}, \mathrm{NH}_{2}\right)$, $5.66(1 \mathrm{H}, \mathrm{d}, \mathrm{J} 6.8,8 \mathrm{~b}-\mathrm{H}), 6.55(1 \mathrm{H}, \mathrm{dd}, 4 \mathrm{~J} 2.1, \mathrm{~J} 7.9,6-\mathrm{H}), 6.63$ $(1 \mathrm{H}, \mathrm{d}, 4 \mathrm{~s} 2.1,8-\mathrm{H})$ and $6.91\left(1 \mathrm{H}, \mathrm{d}, \mathrm{J}\right.$ 7.9, 5- H ); m/z $189\left(\mathrm{M}^{+}\right.$, $100 \%), 144\left(62, \mathrm{C}_{10} \mathrm{H}_{10} \mathrm{~N}\right), 130\left(34, \mathrm{C}_{9} \mathrm{H}_{8} \mathrm{~N}\right)$ and $115\left(10, \mathrm{C}_{9} \mathrm{H}_{7}\right)$.

7-Iodo-3,3a,4,8b-tetrahydroindeno[1,2-b]furan-2-one $12 a$ and 5iodo-3,3a,4,8b-tetrahydroindeno[1,2-b]furan-2-one $12 \mathrm{~b}$

To a solution of the tricyclic lactone $3(100 \mathrm{mg}, 0.575 \mathrm{mmol}$ ) and iodine (146 mg, $0.575 \mathrm{mmol}$ ) in tetrachloromethane (15 $\mathrm{ml}$ ) was added [bis(trifluoroacetoxy)iodo]benzene (272 $\mathrm{mg}$, $0.633 \mathrm{mmol}$ ) with stirring at room temperature A fter $48 \mathrm{~h}$ the solvent was removed from the mixture in vacuo and the residue purified by flash chromatography $\left(\mathrm{SiO}_{2}\right.$, hexane-ethyl acetate, $6: 1)$. Collection of the pure fractions afforded the 7-iodo tricyclic lactone $12 \mathrm{a}$ (65 mg, 38\%) and the 5-iodo tricyclic lactone 12b (48 mg, 28\%) both as white solids. A nalytical samples of $\mathbf{1 2 a}$ and $\mathbf{1 2 b}$ were obtained by recrystallization from dichloromethane-diisopropyl ether.

Compound $12 \mathrm{a}, \mathrm{R}_{\mathrm{f}} 0.30$ (hexane-ethyl acetate, $1: 1$ ), $\mathrm{mp} 110$ $113^{\circ} \mathrm{C}$ (from dichloromethane-diisopropyl ether): $\delta_{\mathbf{H}}(100$ $\left.\mathrm{M} \mathrm{Hz} \mathrm{CDCl}_{3}\right) 2.34\left(1 \mathrm{H}, \mathrm{dd}^{2}{ }^{2} \mathrm{~J} 18.0\right.$, J 5.4, 3- $\left.\mathrm{H}\right), 2.76-3.55(4 \mathrm{H}$, $\mathrm{m}, 3-\mathrm{H}, 4-\mathrm{H}$ and $3 \mathrm{a}-\mathrm{H}), 5.83(1 \mathrm{H}, \mathrm{dj} 6.9,8 \mathrm{~b}-\mathrm{H}), 7.03(1 \mathrm{H}, \mathrm{d}, \mathrm{J}$ 8.0, 5- H ) $7.65(1 \mathrm{H}, \mathrm{dd}, 4 \mathrm{~J} 1.6, \mathrm{~J} 8.0,6-\mathrm{H})$ and $7.80(1 \mathrm{H}, \mathrm{br} \mathrm{s}, 8-$ $\mathrm{H}) ; \mathrm{m} / \mathrm{z} 300\left(\mathrm{M}^{+}, 20 \%\right), 256\left(20, \mathrm{C}_{10} \mathrm{H}_{9} \mathrm{l}\right), 129\left(100, \mathrm{C}_{10} \mathrm{H}_{9}\right)$ and $115\left(18, \mathrm{C}_{9} \mathrm{H}_{7}\right)$ [Found (HRMS): $\mathrm{m} / \mathrm{z}$ 299.9645. Calc. for $\left.\mathrm{C}_{11} \mathrm{H}_{9} \mathrm{OO}_{2}: 299.9649\right]$.

Compound 12b, $\mathrm{R}_{\mathrm{f}} 0.40$ (hexane-ethyl acetate, $1: 1$ ), mp 165$167.5^{\circ} \mathrm{C}$ (from dichloromethane-diisopropyl ether); $\delta_{\mathrm{H}}(100$ $\left.\mathrm{M} \mathrm{Hz} \mathrm{CDCl}_{3}\right) 2.42\left(1 \mathrm{H}, \mathrm{dd}^{2}{ }^{2} \mathrm{j} 18.0\right.$, J 5.1, 3- $\left.\mathrm{H}\right), 2.76-3.38(4 \mathrm{H}$, $\mathrm{m}, 3-\mathrm{H}, 4-\mathrm{H}$ and $3 \mathrm{a}-\mathrm{H}), 5.99(1 \mathrm{H}, \mathrm{d}, \mathrm{J} 6.9,8 \mathrm{~b}-\mathrm{H}), 7.02(1 \mathrm{H}, \mathrm{t}, \mathrm{J}$ 7.6, 7-H ), $7.45(1 \mathrm{H}, \mathrm{d}, \mathrm{J} 7.6,8-\mathrm{H})$ and $7.74(1 \mathrm{H}, \mathrm{d}, \mathrm{J} 7.6,6-\mathrm{H})$; $\mathrm{m} / \mathrm{z} 300\left(\mathrm{M}^{+}, 9 \%\right), 256\left(19, \mathrm{C}_{10} \mathrm{H}_{9} \mathrm{I}\right), 129\left(100, \mathrm{C}_{10} \mathrm{H}_{9}\right)$ and 115 $\left(15, \mathrm{C}_{9} \mathrm{H}_{7}\right)$ [Found (HRM S): $\mathrm{m} / \mathrm{z}$ 299.9648. Calc. for $\mathrm{C}_{11} \mathrm{H}_{9} \mathrm{O}_{2}$ : 299.9649].

7-N itro-3-(4-methyl-5-oxo-2,5-dihydrofuran-2-ylox ymethylene)3,3a,4,8b-tetrahydroindeno[1,2-b]furan-2-one 5 a

Potassium tert-butoxide (563 $\mathrm{mg}, 5.03 \mathrm{mmol}$ ) was added in small quantities to a solution of the 7-nitro tricyclic lactone $4 a$ $(1.00 \mathrm{~g}, 4.57 \mathrm{mmol})$ and methyl formate $(0.84 \mathrm{ml}, 13.7 \mathrm{mmol})$ in THF (35 ml) with stirring at $-78^{\circ} \mathrm{C}$ under nitrogen. The mixture was allowed to warm to room temperature and then stirred for $18 \mathrm{~h}$. A fter the TH F had been removed in vacuo, the residue was dissolved in D M F (35 ml) and the solution was cooled to 
$-60{ }^{\circ} \mathrm{C}$, and treated with the bromo butenolide $7(0.97 \mathrm{~g}, 5.5$ $\mathrm{mmol})$ in DM F $(5 \mathrm{ml})$, added gradually under nitrogen. The mixture was brought to room temperature and stirred for $18 \mathrm{~h}$ after which it was treated with acetic acid $(0.60 \mathrm{~g}, 10 \mathrm{mmol})$; the suspension was then concentrated in vacuo. The residue was dissolved in chloroform and water and the aqueous phase was separated and extracted with chloroform $(2 x)$. The combined organic layers were washed with water $(1 \mathrm{x})$, dried $\left(\mathrm{M} \mathrm{gSO}_{4}\right)$ and concentrated in vacuo. The crude product was purified by flash chromatography $\left(\mathrm{SiO}_{2}\right.$, hexane-ethyl acetate, $\left.1: 1\right)$ to afford two diastereoisomers of $5 \mathrm{a}(549 \mathrm{mg}, 35 \%)\left[R_{\mathrm{f}} 0.12\right.$ and 0.18 (hexane-ethyl acetate, 1:1)] as pale yellow solids. Only the fastmoving diastereoisomer could be obtained in an analytically pure form by recrystallization from ethyl acetate, $\mathrm{mp} 216$ $219{ }^{\circ} \mathrm{C}$ (from ethyl acetate) (Found: $\mathrm{C}, 59.21 ; \mathrm{H}, 3.81 ; \mathrm{N}, 4.11$ $\mathrm{C}_{17} \mathrm{H}_{13} \mathrm{~N} \mathrm{O}_{7}$ requires $\left.\mathrm{C}, 59.48 ; \mathrm{H}, 3.82 ; \mathrm{N}, 4,08\right) ; \delta_{\mathrm{H}}(400 \mathrm{M} \mathrm{Hz}$; $\left.\mathrm{CDCl}_{3}\right) 2.06\left(3 \mathrm{H}, \mathrm{m}, \mathrm{CH}_{3}\right), 3.21\left(1 \mathrm{H}, \mathrm{dd},{ }^{2} \mathrm{~J} 18.0, \mathrm{~J} 3.2,4-\mathrm{H}\right)$, $3.52\left(1 \mathrm{H}, \mathrm{dd},{ }^{2} \mathrm{~J} 18.0, \mathrm{~J}\right.$ 9.3, 4-H ), $4.08(1 \mathrm{H}, \mathrm{m}, 3 \mathrm{a}-\mathrm{H}), 5.99$ (1 $\mathrm{H}, \mathrm{d}, \mathrm{J} 8.0,8 \mathrm{~b}-\mathrm{H}), 6.20(1 \mathrm{H}, \mathrm{m}, \mathrm{OCHO}), 6.97(1 \mathrm{H}, \mathrm{m},=\mathrm{CH})$, $7.39(1 \mathrm{H}, \mathrm{d}, \mathrm{J} 8.4,5-\mathrm{H}), 7.51(1 \mathrm{H}, \mathrm{d}, 4 \mathrm{~J} 2.3,=\mathrm{CH} \mathrm{O}), 8.23(1 \mathrm{H}$, $\mathrm{dd}, 4 \mathrm{~J} 1.9, \mathrm{~J} 8.4,6-\mathrm{H})$ and $8.37(1 \mathrm{H}, \mathrm{d}, 4 \mathrm{~J} 1.9,8-\mathrm{H}) ; \mathrm{m} / \mathrm{z} 343$ $\left(\mathrm{M}^{+}, 1 \%\right), 247\left(2, \mathrm{C}_{12} \mathrm{H}_{9} \mathrm{~N} \mathrm{O}_{5}\right), 219\left(1, \mathrm{C}_{11} \mathrm{H}_{9} \mathrm{~N} \mathrm{O}_{4}\right)$ and $97(100$, $\mathrm{C}_{5} \mathrm{H}_{5} \mathrm{O}_{2}$ ).

7-N itro G R 24 5a could be prepared in an alternative manner by nitration of GR24 using the procedure described for the synthesis of 4a. Starting from G R 24 (100 mg, $0.336 \mathrm{mmol})$, 5a was obtained in $92 \%$ yield. ${ }^{1} \mathrm{H}$ N M R spectroscopic data were in complete agreement with those reported above.

7-lodo-3-(4-methyl-5-ox0-2,5-dihydrofuran-2-yloxymethylene)3,3a,4,8b-tetrahydroindeno[1,2-b]furan-2-one 11

Potassium tert-butoxide (167 mg, $1.64 \mathrm{mmol}$ ) was added in small quantities to a solution of the 7-iodo tricyclic lactone $12 \mathrm{a}$ (447 mg, $1.49 \mathrm{mmol}$ ) and ethyl formate $(1.20 \mathrm{ml}, 14.9 \mathrm{mmol})$ in THF $(25 \mathrm{ml})$ with stirring at $0{ }^{\circ} \mathrm{C}$ under nitrogen. The mixture was allowed to warm to room temperature and then stirred for $18 \mathrm{~h}$. A fter this an excess of acetic acid $(1 \mathrm{ml})$ was added to the mixture which was then evaporated in vacuo to remove the solvent. The mixture was dissolved in ethyl acetate and saturated aqueous $\mathrm{NH}_{4} \mathrm{Cl}$. The aqueous phase was separated and extracted with ethyl acetate $(2 x)$. The combined organic layers were dried $\left(\mathrm{M} \mathrm{gSO}_{4}\right)$ and concentrated in vacuo to give the crude formyl tricyclic lactone as a pale yellow solid. Starting 12a was removed by washing with diethyl ether $(2 x)$ to provide pure hydroxymethyleno lactone as a tautomeric mixture in $50 \%$ yield; $\delta_{\mathrm{H}}\left(100 \mathrm{M} \mathrm{Hz}^{2}\left[{ }^{2} \mathrm{H}_{6}\right.\right.$ ]acetone) 2.85-3.33 (2 H, m, 4-H ), $3.82(1 \mathrm{H}, \mathrm{m}, 3 \mathrm{a}-\mathrm{H}), 5.69(1 \mathrm{H}, \mathrm{d}, \mathrm{J} 7.5,8 \mathrm{~b}-\mathrm{H}), 6.93(1 \mathrm{H}, \mathrm{d}, \mathrm{J}$ 7.7, 5-H ), 7.38-7.61 (3 H, m, 6- H , 8- H, =CHO $)$ and $9.6(1 \mathrm{H}, \mathrm{br}$ $\mathrm{s}, \mathrm{OH})$.

To a solution of thus obtained hydroxymethyleno lactone (150 $\mathrm{mg}, 0.457 \mathrm{mmol})$ in DM F (10 ml) was added potassium tert-butoxide $(56.0 \mathrm{mg}, 0.503 \mathrm{mmol})$ at $0{ }^{\circ} \mathrm{C}$ under a nitrogen atmosphere. The mixture was cooled to $-60^{\circ} \mathrm{C}$ and the bromo butenolide 7 ( $97.0 \mathrm{mg}, 0.548 \mathrm{mmol}$ ) in D M F (2 ml) was gradually added to it. Work-up was similar to that described for the preparation of 7-nitro GR 24 5a (vide supra). Purification by flash chromatography $\left(\mathrm{SiO}_{2}\right.$, hexane-ethyl acetate, $\left.1: 1\right)$ afforded two diastereoisomers in $57 \%$ yield. The fast-moving diastereoisomer of $11\left(R_{f} 0.35\right.$, hexane-ethyl acetate, $\left.1: 1\right)$ was crystallized from ethyl acetate to give $\mathbf{1 1}$ as colourless needles, $\mathrm{mp}$ 206- $209^{\circ} \mathrm{C}$ (from ethyl acetate); $\delta_{\mathrm{H}}\left(100 \mathrm{M} \mathrm{Hz}^{\circ} \mathrm{CDCl}_{3}\right) 2.04$ $\left(3 \mathrm{H}, \mathrm{m}, \mathrm{CH}_{3}\right), 3.03\left(1 \mathrm{H}, \mathrm{dd},{ }^{2} \mathrm{~J} 17.0\right.$, J 3.5, 4-H ), $3.39(1 \mathrm{H}, \mathrm{dd}$, 2) $17.0, \mathrm{~J} 8.8,4-\mathrm{H}), 3.94(1 \mathrm{H}, \mathrm{m}, 3 \mathrm{a}-\mathrm{H}), 5.90(1 \mathrm{H}, \mathrm{d}, \mathrm{J} 7.8,8 \mathrm{~b}-$ $\mathrm{H}), 6.19(1 \mathrm{H}, \mathrm{m}, \mathrm{OCHO}), 6.95(1 \mathrm{H}, \mathrm{m},=\mathrm{CH}), 6.97(1 \mathrm{H}, \mathrm{d}, \mathrm{J}$ 8.0, 5-H ), $7.48(1 \mathrm{H}, \mathrm{d}, 4 \mathrm{~J} 2.5,=\mathrm{CHO}), 7.64(1 \mathrm{H}, \mathrm{dd}, 4 \mathrm{~J} \mathrm{1.6,J}$ 8.0,6-H) and $7.83\left(1 \mathrm{H}, \mathrm{d},{ }^{4} \mathrm{~J} 1.6,8-\mathrm{H}\right) ; \mathrm{m} / \mathrm{z} 424\left(\mathrm{M}^{+}, 4 \%\right), 327$ $\left(26, \mathrm{C}_{12} \mathrm{H}_{8} \mathrm{O}_{3} \mathrm{I}\right)$ and $97\left(100, \mathrm{C}_{5} \mathrm{H}_{5} \mathrm{O}_{2}\right)$ [Found (HRMS): $\mathrm{m} / \mathrm{z}$ 423.9810. Calc. for $\left.\mathrm{C}_{17} \mathrm{H}_{13} \mathrm{IO}_{5}: 423.9804\right]$.

The slow-moving diastereoisomer of $11\left(R_{f} 0.26\right.$, hexaneethyl acetate, $1: 1$ ) was recrystallized from hexane-ethyl acetate to give colourless crystals, mp $189-191{ }^{\circ} \mathrm{C}$ (from hexane-ethyl acetate); the ${ }^{1} \mathrm{H} \mathrm{N} \mathrm{M} \mathrm{R} \mathrm{spectrum}\left(\mathrm{CDCl}_{3}, 100 \mathrm{M} \mathrm{Hz}\right.$ ) was identical with the ${ }^{1} \mathrm{H} N \mathrm{~N} R$ spectrum of the fast-moving diastereoisomer of 11 (vide supra); m/z $424\left(\mathrm{M}^{+}, 6 \%\right), 327\left(34, \mathrm{C}_{12} \mathrm{H}_{8} \mathrm{O}_{3} \mathrm{l}\right)$ and $97\left(100, \mathrm{C}_{5} \mathrm{H}_{5} \mathrm{O}_{2}\right)$ [Found (HRM S): $\mathrm{m} / \mathrm{z}$ 423.9810. Calc. for $\mathrm{C}_{17} \mathrm{H}_{13} \mathrm{IO}_{5}$ : 423.9804].

\section{7-A mino-3-(4-methyl-5-oxo-2,5-dihydrofuran-2-yloxy- methylene)-3,3a,4,8b-tetrahydroindeno[1,2-b]furan-2-one 2a}

A solution of the amino tricyclic lactone la $(440 \mathrm{mg}, 2.33$ $\mathrm{mmol}$ ) and benzaldehyde (247 $\mathrm{mg}, 2.33 \mathrm{mmol}$ ) in ethyl acetate $(20 \mathrm{ml})$, in the presence of molecular sieves $4 \mathrm{~A}$, was stirred for $12 \mathrm{~h}$ at room temperature. A fter this $\mathrm{M} \mathrm{gSO}_{4}$ was added to the mixture which was then filtered over $\mathrm{Hyflo}$ and then concentrated by removal of the solvent in vacuo to give the imine 6 (645 $\mathrm{mg}, 100 \%)$ as a pale yellow solid, which was used immediately in the coupling reaction; $\delta_{\mathrm{H}}\left(100 \mathrm{M} \mathrm{Hz} ; \mathrm{CD} \mathrm{Cl}_{3}\right) 2.36(1 \mathrm{H}$, $\left.\mathrm{dd}^{2}{ }^{2} \mathrm{j} 18.1, \mathrm{~J} 5.4,3-\mathrm{H}\right), 2.70-3.56(4 \mathrm{H}, \mathrm{m}, 3-\mathrm{H}, 4-\mathrm{H}$ and $3 \mathrm{a}-\mathrm{H})$, $5.87(1 \mathrm{H}, \mathrm{d}, \mathrm{J} 6.8,8 \mathrm{~b}-\mathrm{H}), 7.24-7.27(3 \mathrm{H}, \mathrm{m}, \mathrm{Ph}), 7.43-7.53(3$ $\mathrm{H}, \mathrm{m}, \mathrm{Ph}), 7.64-7.94(2 \mathrm{H}, \mathrm{m}, \mathrm{Ph})$ and $8.44(1 \mathrm{H}, \mathrm{s}, \mathrm{N}=\mathrm{CH})$.

To a solution of the freshly prepared imine $6(645 \mathrm{mg}, 2.33$ $\mathrm{mmol}$ ) and methyl formate $(0.5 \mathrm{ml}, 7 \mathrm{mmol})$ in THF (25 ml) was added potassium tert-butoxide $(287 \mathrm{mg}, 2.56 \mathrm{mmol}$ ) in small portions at $0{ }^{\circ} \mathrm{C}$ under nitrogen. The mixture was allowed to warm to room temperature after which it was stirred for $18 \mathrm{~h}$ and then concentrated by removal of the THF in vacuo. The residue was dissolved in DMF $(20 \mathrm{ml})$ and the solution was cooled to $-60{ }^{\circ} \mathrm{C}$ when it was treated with the bromo butenolide 7 (494 mg, $2.70 \mathrm{mmol}$ ) in DM F (3 ml), added gradually under nitrogen. The mixture was brought to room temperature and stirred for $18 \mathrm{~h}$ after which it was concentrated by removal of the solvent in vacuo. The residue was dissolved in dichloromethane and saturated aqueous $\mathrm{NaHCO}_{3}$. The aqueous phase was separated and extracted with dichloromethane $(2 x)$ and the combined organic layers were washed with saturated aqueous $\mathrm{NaHCO}_{3}(1 \mathrm{x})$, dried $\left(\mathrm{M} \mathrm{gSO}_{4}\right)$, and concentrated in vacuo to provide crude 7-benzalimino GR24 (78\%). Flash chromatography $\left(\mathrm{SiO}_{2}\right.$, dichloromethane, followed by ethyl acetatedichloromethane, 3:1) gave 7-amino G R 24 2a (190 mg, 27\%) as a mixture of two inseparable diastereoisomers. Crystallization from butyl acetate afforded $2 \mathrm{a}$ as pale yellow crystals (Found: C, 65.16; $\mathrm{H}, 4.96 ; \mathrm{N}, 4.31 . \mathrm{C}_{17} \mathrm{H}_{15} \mathrm{NO}_{5}$ requires $\mathrm{C}, 65.17 ; \mathrm{H}$, $4.82 ; \mathrm{N}, 4.47) ; \delta_{\mathrm{H}}\left(100 \mathrm{M} \mathrm{Hz} \mathrm{CDCl}_{3}\right) 1.94\left(3 \mathrm{H}, \mathrm{m}, \mathrm{CH}_{3}\right), 2.86(1$ $\left.\mathrm{H}, \mathrm{dd},{ }^{2} \mathrm{~J} 16.3, \mathrm{~J} 3.0,4-\mathrm{H}\right), 3.23\left(1 \mathrm{H}, \mathrm{dd},{ }^{2} \mathrm{~J} 16.3, \mathrm{~J} 8.8,4-\mathrm{H}\right)$, $3.75\left(3 \mathrm{H}, \mathrm{m}, \mathrm{N} \mathrm{H}_{2}\right.$ and $\left.3 \mathrm{a}-\mathrm{H}\right), 5.77(1 \mathrm{H}, \mathrm{d}, \mathrm{J} 7.8,8 \mathrm{~b}-\mathrm{H}), 6.10$ (1 $\mathrm{H}, \mathrm{m}, \mathrm{OCHO}), 6.59(1 \mathrm{H}, \mathrm{dd}, 4 \mathrm{~J} 2.2, \mathrm{~J} 8.0,6-\mathrm{H}), 6.70\left(1 \mathrm{H}, \mathrm{d},{ }^{4} \mathrm{~J}\right.$ $2.28-\mathrm{H}), 6.88(1 \mathrm{H}, \mathrm{m},=\mathrm{CH}), 6.92(1 \mathrm{H}, \mathrm{d}, \mathrm{J} 8.0,5-\mathrm{H})$ and 7.39 $(1 \mathrm{H}, \mathrm{d}, 4 \mathrm{~s} 2.5,=\mathrm{CHO}) ; \mathrm{m} / \mathrm{z} 313\left(\mathrm{M}^{+}, 57 \%\right), 216$ (40, $\left.\mathrm{C}_{12} \mathrm{H}_{10} \mathrm{~N} \mathrm{O}_{3}\right), 188\left(3, \mathrm{C}_{11} \mathrm{H}_{10} \mathrm{~N} \mathrm{O}_{2}\right)$ and $97\left(100, \mathrm{C}_{5} \mathrm{H}_{5} \mathrm{O}_{2}\right)$.

7-A zido-3-(4-methyl-5-oxo-2,5-dihydrofuran-2-ylox ymethylene)3,3a,4,8b-tetrahydroindeno[1,2-b]furan-2-one 8

Sodium nitrate ( $33 \mathrm{mg}, 0.48 \mathrm{mmol}$ ) was added to a solution of a mixture of the diastereoisomers of 7-amino GR $242 \mathrm{a}(138 \mathrm{mg}$, $0.44 \mathrm{mmol})$ in $80 \%$ acetic acid $(20 \mathrm{ml})$ at $0{ }^{\circ} \mathrm{C}$ with protection from light. A fter $5 \mathrm{~min}$ sodium azide ( $32 \mathrm{mg}, 0.48 \mathrm{mmol}$ ) was added to the mixture and stirring was continued for $2 \mathrm{~h}$. The mixture was then concentrated in vacuo and the residue was dissolved in ethyl acetate and saturated aqueous $\mathrm{NaHCO}_{3}$. The aqueous phase was separated and extracted with ethyl acetate $(2 x)$ and the combined organic layers were washed with saturated aqueous $\mathrm{NaHCO}_{3}(1 \times)$, dried $\left(\mathrm{M} \mathrm{gSO}_{4}\right)$ and concentrated in vacuo. Purification of the residue by flash chromatography $\left(\mathrm{SiO}_{2}\right.$, hexane-ethyl acetate $\left.1: 1\right)$ afforded two diastereoisomers of 8 ( $131 \mathrm{mg}, 88 \%)$ as white solids.

Fast-moving diastereoisomer of $\mathbf{8}, \mathrm{R}_{\mathbf{f}} 0.29$ (hexane-ethyl acetate, $1: 1), \mathrm{mp} 151-154^{\circ} \mathrm{C} ; v_{\max }\left(\mathrm{CCl}_{4}\right) / \mathrm{cm}^{-1} 2120\left(\mathrm{~N}_{3}\right), 1795$ $(\mathrm{C}=0), 1765(\mathrm{C}=0)$ and $1685(\mathrm{C}=\mathrm{C}$, enol ether $) ; \delta_{\mathrm{H}}(100 \mathrm{M} \mathrm{Hz}$; $\left.\mathrm{CDCl}_{3}\right) 2.04\left(3 \mathrm{H}, \mathrm{m}, \mathrm{CH}_{3}\right), 3.06\left(1 \mathrm{H}, \mathrm{dd},{ }^{2} \mathrm{~J} 16.7, \mathrm{~J} 3.6,4-\mathrm{H}\right)$, $3.41\left(1 \mathrm{H}, \mathrm{dd},{ }^{2} \mathrm{~J} 16.7, \mathrm{~J} 8.8,4-\mathrm{H}\right), 3.96(1 \mathrm{H}, \mathrm{m}, 3 \mathrm{a}-\mathrm{H}), 5.91$ 
$(1 \mathrm{H}, \mathrm{d}, \mathrm{J} 7.8,8 \mathrm{~b}-\mathrm{H}), 6.19(1 \mathrm{H}, \mathrm{m}, \mathrm{OCHO}), 6.93-7.25(4 \mathrm{H}$, $\mathrm{m}, \mathrm{Ph}$ and $=\mathrm{CH})$ and $7.48(1 \mathrm{H}, \mathrm{d}, 4 \mathrm{~J} 2.5,=\mathrm{CHO}) ; \mathrm{m} / \mathrm{z} 339$ $\left(\mathrm{M}^{+}, 2 \%\right), 313\left(1, \mathrm{C}_{17} \mathrm{H}_{15} \mathrm{~N} \mathrm{O}_{5}\right), 214\left(2, \mathrm{C}_{12} \mathrm{H}_{8} \mathrm{~N} \mathrm{O}_{3}\right)$ and $97(100$, $\mathrm{C}_{5} \mathrm{H}_{5} \mathrm{O}_{2}$ [F ound (HRM S): $\mathrm{m} / \mathrm{z}$ 339.0856. Calc. for $\mathrm{C}_{17} \mathrm{H}_{13} \mathrm{~N}_{3} \mathrm{O}_{5}$ : 339.0855].

Slow-moving diastereoisomer of $\mathbf{8}, \mathrm{R}_{\mathrm{f}} 0.19$ (hexane-ethyl acetate, $1: 1)$, mp $164-167^{\circ} \mathrm{C}$; the ${ }^{1} \mathrm{H} N \mathrm{NM}$ spectrum $\left(\mathrm{CDCl}_{3}\right.$, $100 \mathrm{M} \mathrm{Hz}$ ) was identical with the ${ }^{1} \mathrm{H} N \mathrm{NM}$ spectrum of the fast-moving diastereoisomer of 8; m/z $339\left(\mathrm{M}^{+}, 2 \%\right), 311$ (3, $\left.\mathrm{C}_{17} \mathrm{H}_{13} \mathrm{~N} \mathrm{O}_{5}\right), 215\left(3, \mathrm{C}_{12} \mathrm{H}_{8} \mathrm{~N} \mathrm{O}_{3}\right)$ and $97\left(100, \mathrm{C}_{5} \mathrm{H}_{5} \mathrm{O}_{2}\right)$ [Found (HRM S): $\mathrm{m} / \mathrm{z}$ 339.0.856. Calc. for $\mathrm{C}_{17} \mathrm{H}_{13} \mathrm{~N}_{13} \mathrm{O}_{5}$ : 339.0855].

\section{$\mathrm{N}$-[3-(4-M ethyl-5-ox0-2,5-dihydrofuran-2-yloxymethylene)-2- oxo-3,3a,4,8b-tetrahydro-2H -indeno[1,2-b]furan-7-yl]-5- dimethylaminonaphthalene-1-sulfonamide 10}

A mixture of slow- and fast-moving 7-amino G R 24 2a (170 mg, $0.543 \mathrm{mmol}$ ) and dansyl chloride (146 $\mathrm{mg}, 0.543 \mathrm{mmol}$ ) were dissolved in pyridine $(10 \mathrm{ml})$ and the solution was stirred for $65 \mathrm{~h}$ with protection from light. A fter this, the mixture was concentrated by removal of the solvent in vacuo and the residue was dissolved in ethyl acetate and $5 \%$ aqueous oxalic acid. The aqueous phase was separated and extracted with ethyl acetate $(2 x)$, and the combined organic layers were washed with $5 \%$ aqueous oxalic acid $(1 \mathrm{x})$, dried $\left(\mathrm{M} \mathrm{gSO}_{4}\right)$ and concentrated in vacuo. The crude product was purified by flash chromatography $\left(\mathrm{SiO}_{2}\right.$, hexane-ethyl acetate, $\left.1: 1\right)$ to provide two diastereoisomers of $10(264 \mathrm{mg}, 89 \%)$ as pale yellow solids with $R_{f} 0.2$ and 0.17 (hexane-ethyl acetate, $1: 1$ ). A $n$ analytically pure sample of the fast-moving diastereoisomer of 10 was obtained by recrystallization from diisopropyl ether-dichloromethane, $\mathrm{mp}$ 186- $188^{\circ} \mathrm{C}$ (from diisopropyl ether-dichloromethane) (F ound: $\mathrm{C}, 63.50 ; \mathrm{H}, 4.83 ; \mathrm{N}, 5.10 ; \mathrm{S}, 5.83 . \mathrm{C}_{29} \mathrm{H}_{26} \mathrm{~N}_{2} \mathrm{O}{ }_{7} \mathrm{~S}$ requires $\mathrm{C}$, $63.73 ; \mathrm{H}, 4.79 ; \mathrm{N} ; 5.13 ; \mathrm{S}, 5.83) ; \delta_{\mathrm{H}}\left(400 \mathrm{M} \mathrm{H} \mathrm{Z} ; \mathrm{CD} \mathrm{Cl}_{3}\right) 2.03(3 \mathrm{H}$ $\mathrm{m}, \mathrm{CH}_{3} \mathrm{D}$-ring), $2.88\left[6 \mathrm{H}, \mathrm{s}, \mathrm{N}\left(\mathrm{CH}_{3}\right)_{2}\right], 2.96\left(1 \mathrm{H}, \mathrm{dd},{ }^{2} \mathrm{]} 16.4\right.$, J 3.5, 4-H ), $3.28\left(1 \mathrm{H}, \mathrm{dd},{ }^{2} \mathrm{~J} 16.4, \mathrm{~J} 9.4,4-\mathrm{H}\right), 3.86(1 \mathrm{H}, \mathrm{m}$, 3a-H), $5.72(1 \mathrm{H}, \mathrm{d}, \mathrm{J}$ 8.2, 8b-H), $6.14(1 \mathrm{H}, \mathrm{m}, \mathrm{OCHO}), 6.81$ $(1 \mathrm{H}, \mathrm{s}, \mathrm{NH}), 6.92(1 \mathrm{H}, \mathrm{m},=\mathrm{CH}), 6.96(1 \mathrm{H}, \mathrm{s}, 8-\mathrm{H}), 7.00(2 \mathrm{H}, \mathrm{s}$, 5-H and 6-H ), $7.19(1 \mathrm{H}, \mathrm{d}, \mathrm{J}$ 7.6, Ph dansyl), $7.42(1 \mathrm{H}, \mathrm{t}, \mathrm{J} 7.6$ Ph dansyl), $7.43(1 \mathrm{H}, \mathrm{d}, 4 \mathrm{~J} 2.4,=\mathrm{CHO}), 7.59(1 \mathrm{H}, \mathrm{t}, \mathrm{J}$ 8.4, Ph dansyl), 8.14 ( $1 \mathrm{H}, \mathrm{d}, \mathrm{J}$ 7.6, Ph dansyl), $8.31(1 \mathrm{H}, \mathrm{d}, \mathrm{J}$ 8.4, $\mathrm{Ph}$ dansyl) and 8.50 (1 H, d, J 8.4, $\mathrm{Ph}$ dansyl); $\mathrm{m} / \mathrm{z} 450$ $\left(\mathrm{M}^{+}+1-\mathrm{C}_{5} \mathrm{H}_{5} \mathrm{O}_{2}, \quad 1 \%\right), \quad 422 \quad\left(3, \quad \mathrm{C}_{23} \mathrm{H}_{22} \mathrm{~N}_{2} \mathrm{O}{ }_{4} \mathrm{~S}\right), \quad 217 \quad(11$, $\left.\mathrm{C}_{12} \mathrm{H}_{11} \mathrm{NO}_{3}\right), 171\left(2, \mathrm{C}_{12} \mathrm{H}_{13} \mathrm{~N}\right), 97\left(12, \mathrm{C}_{5} \mathrm{H}_{5} \mathrm{O}_{2}\right)$ and $28(100$, $\mathrm{CO})$; fluorescence (c $2.0 \mathrm{~mm}, \mathrm{M} \mathrm{eOH}): \lambda_{\text {exc. }} 350 \mathrm{~nm}\left(\varepsilon 4.12^{*} 10^{3}\right)$, $\lambda_{\text {em. }} 525 \mathrm{~nm}$.

\section{N-[3-(4-M ethyl-5-ox0-2,5-dihydrofuran-2-yloxymethylene)-2- ox0-3,3a,4,8b-tetrahydro-2H -indeno[1,2-b]furan-7-yl]- methanesulfonamide 9}

The procedure described for the preparation of 10 was followed using amino G R 24 2a (100 mg, $0.320 \mathrm{mmol})$, methanesulfonyl chloride $(36.6 \mathrm{mg}, 0.320 \mathrm{mmol})$ and pyridine $(10 \mathrm{ml})$. Workup followed by purification by flash chromatography $\left(\mathrm{SiO}_{2}\right.$, dichloromethane-ethyl acetate, $3: 1$ ) gave methanesulfonyl G R 24 9 (98 mg, 78\%) as a mixture of inseparable diastereoisomers. Recrystallization of the residue from ethanol afforded 9 as a white solid (Found: $\mathrm{C}, 54.89 ; \mathrm{H}, 4.24 ; \mathrm{N}, 3.72 ; \mathrm{S}, 8.08 . \mathrm{C}_{18} \mathrm{H}_{17^{-}}$ $\mathrm{N} \mathrm{O}_{7} \mathrm{~S}$ requires $\left.\mathrm{C}, 55.24 ; \mathrm{H}, 4.38 ; \mathrm{N}, 3.58 ; \mathrm{S}, 8.19\right) ; \delta_{\mathrm{H}}(100 \mathrm{M} \mathrm{Hz}$; $\left.\mathrm{CDCl}_{3}\right) 2.05\left(3 \mathrm{H}, \mathrm{m},=\mathrm{CH}_{3}\right), 2.97\left(3 \mathrm{H}, \mathrm{s}, \mathrm{SCH}_{3}\right) 3.05(1 \mathrm{H}, \mathrm{dd}$, 2) $16.9, \mathrm{~J} 3.04-\mathrm{H}), 3.39\left(1 \mathrm{H}, \mathrm{dd},{ }^{2} \mathrm{~J} 16.9, \mathrm{~J} 8.8,4-\mathrm{H}\right), 3.96(1 \mathrm{H}$, $\mathrm{m}, 3 \mathrm{a}-\mathrm{H}), 5.92(1 \mathrm{H}, \mathrm{d}, \mathrm{J} 7.8,8 \mathrm{~b}-\mathrm{H}), 6.21(1 \mathrm{H}, \mathrm{m}, \mathrm{OCH} 0), 7.00$ $(1 \mathrm{H}, \mathrm{m},=\mathrm{CH}), 7.14-7.27(4 \mathrm{H}, \mathrm{m}, \mathrm{Ph}$ and $\mathrm{NH})$ and $7.54(1 \mathrm{H}$, d, 4 J 2.5, =CH O); m/z $391\left(\mathrm{M}^{+}, 1 \%\right), 295\left(3, \mathrm{C}_{13} \mathrm{H}_{13} \mathrm{~N} \mathrm{O}_{5} \mathrm{~S}\right), 216$ $\left(1, \mathrm{C}_{12} \mathrm{H}_{10} \mathrm{~N} \mathrm{O}_{3}\right), 97\left(12, \mathrm{C}_{5} \mathrm{H}_{5} \mathrm{O}_{2}\right)$ and $28(100, \mathrm{CO})$

\section{B iological activity}

Seeds. Seeds of Striga hermonthica and O robanche crenata were harvested in Sudan in 1987 and in Eygpt in 1991, respectively and were stored in the dark at room temperature until used in germination tests.
Preparation of test solutions. A compound (10 mg) to be tested was weighed out very accurately, dissolved in acetone p.a. $(10 \mathrm{ml})$ and diluted with demineralized water to $100 \mathrm{ml}$. A liquots of this stock solution were further diluted with water to obtain test solutions containing $1,0.1,0.01$ and $0.001 \mathrm{mg} \mathrm{I}^{-1}$ test compound and $0.1,0.01,0.001$ and $0.0001 \%(\mathrm{v} / \mathrm{v})$ of acetone, respectively.

B ioassays. For sterilization, seeds of Striga hermonthica and $O$ robanche crenata were exposed to an aqueous sodium hypochlorite ( $2 \%$ active chlorine) for $5 \mathrm{~min}$ with agitation. The seeds were then thoroughly rinsed with water and dried overnight.

For conditioning the sterilized seeds were spread on glass fibre filter paper disks (8 $\mathrm{mm}$ diameter; approximately 30-70 seeds per disk) in Petri dishes, moistened with water and stored in the dark for 14 days at $20^{\circ} \mathrm{C}$ for 0 robanche seeds and at $30^{\circ} \mathrm{C}$ for Striga seeds. The conditioning water was then removed and replaced by $100 \mu \mathrm{l}$ of test solution per disk. A fter incubation for $24 \mathrm{~h}$ (Striga) and 5 days (O robanche) in the dark at the indicated temperatures, the germination percentage was determined under a microscope. Seeds were considered to be germinated if the radical protruded through the seed coat.

In each test series aqueous solutions with $0.1,0.01,0.001$ and $0.0001 \%(\mathrm{v} / \mathrm{v})$ of acetonewereused as negative control. Test solutions of the stimulant G R 24 (concentrations of 1, 0.1, 0.01 and $0.001 \mathrm{mg} \mathrm{l}^{-1}$ ) were used as positive controls. A II tests were performed in duplicates, and in each test the germination percentages were determined on 12 disks. For full details of the bioassay, see ref. 27.

\section{Acknowledgements}

We thank Dr A. G. T. Babiker and Dr F. M. F. Zaitoun for supplying Striga and $O$ robanche seeds. We thank $H$. A matdjais, P. van $G$ alen and A. Swolfs for conducting elemental analysis, mass and $400 \mathrm{M} \mathrm{Hz}^{1} \mathrm{H} \mathrm{N} \mathrm{M} \mathrm{R}$ measurements, respectively. These investigations were supported by the $\mathrm{N}$ etherlands Foundation of Chemical Research (SON) with financial aid from the $\mathrm{N}$ etherlands Organization for the A dvancement of Research (N WO).

\section{R eferences}

$1 \mathrm{~L}$. J. M usselman, Ed. Parasitic W eeds in A griculture, Vol. I, Striga, CRC Press, Boca Raton, F L., 1987, 317.

2 C. Parker, Scope of the agronomic problems caused by Orobanche species, in Proceedings of a Workshop on Biology and Control of Orobanche, ed. S. J. ter Borg, LH/NPO, Wageningen, The N etherlands, 1986, p. 11.

3 C. E. Cook, L. P. Whichard, M. E. Wall, G. H. Egley, P. Coggan, P. A . L uhan and A. T. M cPhail, J. A m. Chem. Soc., 1972, 94, 6198.

4 D. W. Brooks, H. S. Bevinakatti and D. R. Powell, J. Org. Chem., 1985, 50, 3779.

5 A. W. Johnson, G. Roseberry and C. Parker, Weed Res, 1976, 16, 233.

6 A. W. Johnson, G. Gowda, A. Hassanali, J. K nox, S. M onaco, Z. Razawi and G. Roseberry, J. Chem. Soc., Perkin Trans. 1, 1981, 1734.

7 S. L. Vail, O. D. Dailey, E. J. Blanchard, A. B. Pepperman and J. L. R iopel, J. P lant Growth Regul., 1990, 9, 77.

8 E. M. M angnus and B. Zwanenburg, J. A gric. Food Chem., 1992, 40, 1066

9 E. M. M angnus, L. A. van Vliet, D. A. L. Vandenput and B. Zwanenburg, J. A gric. Food Chem., 1992, 40, 1222.

10 E. M. M angnus and B. Zwanenburg, Recl. Trav. Chim. Pays-Bays, 1992, 111, 155

11 E. M. M angnus, F. J. D ommerholt, R. L. P. de Jong and B. Zwanenburg, J. A gric. Food Chem., 1992, 40, 1230.

12 R. J. Weselake and J. C. Jain, P hysiol. P lant., 1992, 84, 301.

$13 \mathrm{H}$. Bayley and J. R. K nowles, M ethods Enzymol., 1977, 46, 69.

14 For a recent review of chemical reagents in photoaffinity labelling, see S. A . F leming, Tetrahedron, 1995, 51, 12479.

15 A. M. Jones and M. A. Venis, Proc. N atl. A cad. Sci. U SA, 1986, 86, 6153. 
16 R. P. Walker, W. M. Waterworth, M. H. Beale and R. H ooley, Plant Growth R egul., 1994, 15, 271.

$17 \mathrm{~A}$. Hassanali, Strigol analogues: Synthetic achievements and prospects, in Striga: Biology and Control, ed. E. S. Ayensu, H. D oggett, R. D. K eynes, J. M arton-L efevre, L. J. M usselman and C. Parker, ICSU Press, Paris, 1984, pp. 125-132.

$18 \mathrm{~S}$. U emura, A. Toshimitsu and M. Okano, J. Chem. Soc., Perkin. Trans. 1, 1978, 1076.

19 J. A . Cowan, Tetrahedron L ett., 1986, 27, 1205.

20 K. M. D oxsee, M. Fiegel, K. D. Stewart, J. W. Canary, C. B. K nobler and D. J. Cram, J. A m. Chem. Soc., 1987, 109, 3098.

21 K. G. Pinney and J. A. K atzenellenbogen, J. O rg. Chem., 1991, 56, 3125 .

22 C. M. H imel, W. G. A boul-Saad and S. U k, J. A gric. Food Chem., $1971,19,1175$.

23 For experimental details see: J. W. J. F. Thuring, Thesis, 1996, $\mathrm{U}$ niversity of $\mathrm{N}$ ijmgen, The $\mathrm{N}$ etherlands.
24 E. B. M erkushev, N. D. Simakhina and G. M. Koveshnikova, Synthesis, 1980, 486.

25 J. W. J. F. Thuring, A . A . M . A . van G aal, S. J. H ornes, M . M . K . de K ok, G. H. L. N efkens and B. Zwanenburg, J. Chem. Soc., Perkin Trans. 1, 1997, 767.

26 J. W. J. F. Thuring, H. H. Bitter, M. M. K. de Kok, G. H. L. N efkens, A. M . D. A. van R iel and B. Z wanenburg, J. A gric. Food. Chem., in the press.

27 E. M. M agnus, P. L. A. Stommen and B. Zwanenburg, J. Plant Growth R egul., 1992, 11, 91.
Paper 6/04685A

Received 4th J uly 1996 A ccepted 16th O ctober 1996 